\title{
DEVELOPMENT OF SCIENCE STUDENT WORKSHEET BASED ON PROJECT BASED LEARNING MODEL TO IMPROVE COLLABORATION AND COMMUNICATION SKILLS OF JUNIOR HIGH SCHOOL STUDENT
}

\author{
Kartika Arum Sari, Zuhdan Kun Prasetyo, and Widodo Setiyo Wibowo \\ Science Education, Yogyakarta State University \\ kartikaas04@gmail.com
}

\begin{abstract}
This research aims to (1) produce a reasonable science student worksheet to improve collaboration and communication skills of junior high school student, (2) - determine the student's collaboration skills training by the Wadi worksheet, (3) • determine the student's communication skils training by the Wadi worksheet, (4) • determine the student's response after using the worksheets. This research is $R D$ with $4 D \&$ models (Define, Design, Develop, and Disseminate). The instruments used in this research consisted of validation form of science student worksheet, the student's questionnaire response form, the form of learning process with project based learning models, self-just my assesment of collaboration skills, peer-just my assesment of collaboration skills, observation sheet of collaboration skills, and observation sheet of communication skills. The data were analyzed using qualitative and quantitative analysis. Qualitative analysis for the data of worksheet's validation and students's response. Quantitative analysis for collaboration skills training of self-just my assesment; Peer-just my assesment; and observation sheet data and communication skills training of observation sheet data that for both of them by percentage calculations-gain score calculation U Mann-Whitney, and for percentage of learning process. The result showed that (1) the worksheet that has produced was reasonable to improve collaboration and communication skills of junior high school student; (2) student's collaboration skills training have moderate categories, $31.54 \%$ from it is "enough" to be "good" with significantly difference before and after using the worksheet score, by signification value (Sig) was 0.000; (3) the student's communication skills training have moderate categories, it is $47.96 \%$ from "less" to be "good" with significantly difference before and after using the worksheet score, by signification value (Sig) was 0.000; (4) the student's response got the worksheet with very well categories $(A)$.
\end{abstract}

Keywords: collaboration skills, communication skills, project based learning, science student worksheet

\section{INTRODUCTION}

Education has a strategic role to prepare the young generation who meet qualifications appropriate to the challenges of the 21 st century, which includes skills that focus on the skills of learning innovation (1) critical thinking and problem solving; (2) communication and collaboration; and (3) creativity and invention (Trilling, 2009: 49). In the meantime, based on English Skills Report (2010: 37) States that team skills and communication skills (collaboration) rated be the skills most needed in the world of work. Therefore, the necessary communication and collaboration skills are grown early on.

World Education contributes in generating qualified workforce of the 21 st century, so that it can link and match with the real needs of the business world and the job market. Demikin however, at the moment a lot of practice learning the IPA lacking build skills needed in the workforce, especially the skills of communication and collaboration.

Based on early observations conducted in SMP N 1 clove cigarettes obtained problems: (1) the collaborative skills of learners is still low, indicated by the absence of a clear division of tasks at the moment are working together in groups and lack of sense of value the between group members; (2) communication skills also are still characterized by low skills speaking learners is not good; (3) teachers very rarely use the learning materials in the form of science student worksheet and if using only refers to the text book and there is no development of teachers.

These problems indicate that there are still learning in learners a less controlled collaboration 
and communication skills. One of the reasons, is due to the inaccuracy of the learning model applied and lack of learning materials. Then, as the solution of learning need to apply the model of project based learning (the execution) which has a stage able to guide learners to develop both of these skills by facilitating learners to berinvestigasi, solve problems, are studentcentered, and produce real results of projects (Yuni Wibowo, et al, 2015: 49) as Matthew Widodo Wibowo (2014) which suggests that the execution is one of the models that are able to achieve menjembantani 4Cs Skills such as collaboration and communication skills. According to Santyasa in (Melda Ariyanti, 2017:3) that "in project based learning, collaborative dilkukan project and innovative, unique, focused on solving problems related to the lives of the learners". In addition, he had to do the development of learning materials in the form of the development of Learner Worksheets (LKPD). The determination of that constituted this LKPD the kinds of learning materials, LKPD is the most variable in accordance with the research.

Based on the thinking that has been outlined above, then it's very important research done by title: "The development of Learner Worksheets IPA-based Project Based Learning to Increase the skills of collaboration and communication skills Learners Class VII".

\section{RESEARCH METHODS}

This research is a research and development by implementing $4 \mathrm{~d}$ models in accordance with Thiagarajan \& Semmel (1974:59).

\section{Time and place of Research}

The research was carried out in December 2016-April 2017. Field trials in April 2017 in SMP N 1 clove cigarettes.

\section{Target/Subject}

Subjects in the study were 27 learners classes VII B SMP N 1 clove cigarettes.

\section{Object of Research}

Objects in research-based science student worksheet the execution is to increase collaboration and communication skills learners Class VII.

\section{Procedure}

This research consists of four stages, namely the stage define, design, develop, and disseminate. Stage define consists of the initial analysis, analysis of the learners, analysis tasks, concepts, analysis and formulation of learning objectives. Stage design consists of a drafting instrument, selection of media or materials, choice of format, and the initial draft. Develop phase consists of validation by expert lecturers and teachers of the IPA, and then conducted trials of development. Disseminate stage done in limited spread to the teacher in junior high school $\mathrm{N} 1$ clove cigarettes.

\section{Data, Instruments, and Data collection Techniques}

The instruments used in this research in the form of sheets, science student worksheet question form validation response learners against science student worksheet, observation sheets keterlaksanaan learning, collaboration skills selfassessment question form, the now antarteman assessment skills of collaboration, collaborative skills, observation sheets and sheets of observation 
skills of communication. Data Analysis Techniques

Technique of data analysis used in this study are as follows.

1. Analysis of The Results of The Validation Science Student Worksheet

Data obtained from the results of the validation are analyzed to find out the feasibility of LKPD IPA with based on table 1.

Table 1. The actual Score Conversion became a value Scale of five (Eko Putro Widoyoko, 2009: 237)

\begin{tabular}{llll}
\hline No. & Score range & $\begin{array}{l}\text { The } \\
\text { value } \\
\text { of the }\end{array}$ & Category \\
\hline 1. & $X>\bar{X}_{i}+1,8 \times s b_{i}$ & A & $\begin{array}{l}\text { Very } \\
\text { good }\end{array}$ \\
\hline 2. & $\bar{X}_{i}+0,6 \times s b_{i}<X \leq$ & B & Good \\
& $\bar{X}_{i}+1,8 x s b_{i}$ & & \\
\hline 3. & $\bar{X}_{i}-0,6 \times s b_{i}<X \leq$ & C & Enough \\
& $\bar{X}_{i}+0,6 \times s b_{i}$ & & \\
\hline 4. & $\bar{X}_{i}-1,8 \times s b_{i}<X \leq$ & D & Less \\
& $\bar{X}_{i}-0,6 \times s b_{i}$ & E & Very Less \\
\hline 5. & $X \leq \bar{X}_{i}-1,8 \times s b_{i}$ & E \\
\hline
\end{tabular}

Description:

$\mathrm{X}=$ actual score

SBI = raw score is ideally Byway

Maximal ideal score $=$ grain criteria $\mathrm{x}$ highest score

Maximal ideal score $=$ grain criteria $\mathrm{x}$ highest score

Then reliability and validation expert lecturers and teachers IPA can be set with the formula Borich (2003: 285).

$$
P A=100 \%\left\{1 \frac{(A-B)}{(A+B}\right\}
$$

Description:

$\mathrm{PA}=$ The Precentages of Agreement (Reliability)

A $=$ highest score

B = lowest score

The results of the validation LKPD IPA reliability if it has reliability above $75 \%$.

2. Analysis Of Learner Response Against LKPD IPA
The results were analyzed with learner response calculation of average score each aspect of the assessment are then converted in accordance with table 1 .

3. The Analysis Of Collaborative Skills Learners An analysis of skills of collaboration with the calculation of the average of the data sheet observations, self-assessment, and the judgment antarteman the percentage calculation is then converted according the table 2 .

Table 2. Manual Conversion Percentage Interval Into Categories

\begin{tabular}{|c|c|c|}
\hline No. & Percentage (\%) & Category \\
\hline 1. & $\begin{array}{l}80<\quad \mathrm{X} \leq \quad 100 \\
\mathrm{X} \leq="{ }^{\prime}=</ \mathrm{X} \leq 100>\end{array}$ & Very good \\
\hline 2. & $\begin{array}{l}60<\mathrm{X} \leq 80 \quad \mathrm{X}=" " " \\
\leq=" "></ \mathrm{X} \leq 80>\end{array}$ & Good \\
\hline 3. & $\begin{array}{l}60<X \leq 80 \quad X=" " \\
\leq=" "></ X \leq 80>\end{array}$ & Enough \\
\hline 4. & $\begin{array}{l}60<\mathrm{X} \leq 80 \quad \mathrm{X}=" " \\
\leq=" "></ \mathrm{X} \leq 80>\end{array}$ & Less \\
\hline 5. & $\begin{array}{l}60<\mathrm{X} \leq 80 \quad \mathrm{X}=" " \\
\leq=" "></ \mathrm{X} \leq 80>\end{array}$ & Very Less \\
\hline
\end{tabular}

(Source: Eko Putro Widoyoko, 2014: 144)

Furthermore, with the calculation of the gain score then converted according the table 3.

Table 3. Standard Value Conversion Gain Be Qualitative Data

\begin{tabular}{l|l}
\hline The value of the & Category \\
\hline$(\langle g\rangle) \geq 0,7$ & High \\
\hline 0,7$\rangle(\langle g\rangle) \geq 0,3$ & Is being \\
\hline$(<g\rangle)<0,3$ & Low \\
\hline
\end{tabular}

(Source: Hake, 1998: 65)

Then test with a significance test, MannWhitney U with a hypothesis:

$\mathrm{H} 0=$ there is no difference before and after collaboration skills using LKPD

$\mathrm{H} 0=$ there is no difference before and after collaboration skills using LKPD

As for the decision criteria used is if the value of Asymp. SIG (2-tailed)< 0,05 maka H0 ditolak, Jika nilai Asymp. 0,05="" maka="" h0="" ditolak,="" jika="" nilai=""></ 0,05 maka H0 
ditolak, Jika nilai Asymp.> SIG (2-tailed) > 0.05 then $\mathrm{H} 0$ are received.

\section{Analysis Of Communication Skills}

Analysis of communication skills with the calculation of the percentages was converted in accordance table 2 calculation and gain score with the conversion of the qualitative data fit score being table 3. Next U-Mann Whitney test with a hypothesis:

$\mathrm{H} 0=$ there is no difference in communication skills before and after using LKPD

$\mathrm{H} 0=$ there is no difference in communication skills before and after using LKPD

As for the criteria for the decision are the same skills analysis collaboration.

\section{THE RESULTS OF THE RESEARCH AND THE DISCUSSION}

1. Product Validation LKPD IPA

LKPD IPA developed rated by expert lecturers and teachers of the IPA. Validation is performed against the component that includes LKPD (title, basic competencies, lesson learned, supporting information, tasks/steps work, judgments) and feasibility feasibility include LKPD content, linguistic, presentation, and kegrafisan. Based on the assessment of expert lecturers and teachers of SCIENCE, overall LKPD stated worth with excellent category $(\mathrm{A})$.

Reliability analysis based on the results obtained and $93.72 \%$ percentage of $99.25 \%$ on validation and feasibility component against LKPD IPA.

2. Learner Response

Dididk participant response against LKPD IPA review of eligibility and Execution-based
LKPD LKPD on sub aspects of the sentence and the linguistic clarity of presentation, questions, kemenarikan appearance LKPD, and consistency of the writing obtained an A category very well.

3. Collaboration Skills Improvement

The results increased collaboration skills learners in mind based on the results of the initial assessment before using LKPD and final assessment after using LKPD shown in table 4.

Table 4. Data On The Percentage Of Collaborative Skills

\begin{tabular}{l|l|l}
\hline \multirow{2}{*}{ Indicator } & \multicolumn{2}{|c}{$\begin{array}{c}\text { The Percentage of Ket. } \\
\text { Collaboration (\%) }\end{array}$} \\
\cline { 2 - 3 } & $\begin{array}{c}\mid c \\
\text { value of the } \\
\text { beginning }\end{array}$ & $\begin{array}{c}\text { value of the } \\
\text { ending }\end{array}$ \\
\hline Contribute actively & 31.48 & 70.58 \\
\hline Productive work & 68.52 & 84.92 \\
\hline $\begin{array}{l}\text { Demonstrates } \\
\text { flexibility } \\
\text { compromise } \&\end{array}$ & 61.11 & 79.92 \\
\hline $\begin{array}{l}\text { Manage the project } \\
\text { well }\end{array}$ & 5.56 & 78.25 \\
\hline Responsible friends & 50.93 & 80.33 \\
\hline Appreciate fris & 86.00 \\
\hline Average & 48.46 & 80.00 \\
\hline
\end{tabular}

Based on average percentage value then increases collaboration skills of $31.54 \%$ of the category simply be good while the results of the analysis show that the increase in gain score categories are of 0.61 . The following graph from collaborative skills increase average score assessment of the beginning and end of 11.63 and 19.20 .

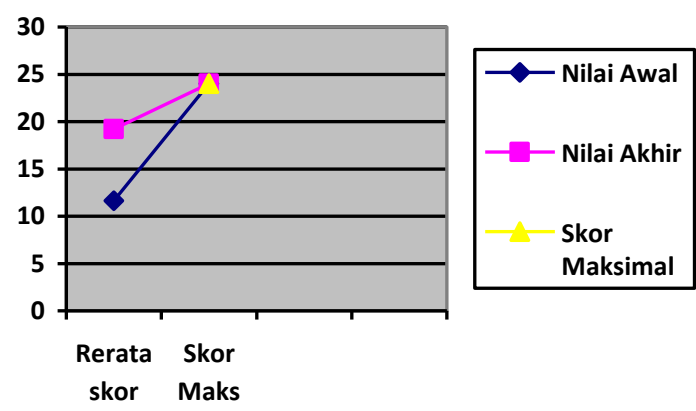

Figure 1. Diagram Collaboration Skills Improvement

The results of the statistical analysis of the non parametris with U-mann Whitney test also showed LKPD IPA can improve collaboration 
skills learners significantly with Asymp. SIG (2tailed) 0.000 .

Based on the above description, then LKPD IPA-based model of project based learning can improve significantly the collaboration skills learners. This is in accordance with the opinion of the Han (Bhatttacharya \& Orey, 2010: 140) that identifies five advantages of implementation of project-based learning and one of them was to improve the skills of collaboration. In addition, Learning with a model of project based learning can train and improve the skills of collaboration because they can fulfill things needed in learning to develop collaboration skills as Igballe et al (2014: 52) that the execution of the most important things is a collaborative team work where learners are required to work together, share ideas, organize and memenejemen deadline assignment.

4. Improved Communication Skills

Results improved communication skills are presented in table 5.

Table 5. Percentage Of Data Communication Skills

\begin{tabular}{l|l|l}
\hline \multirow{2}{*}{ Indicator } & \multicolumn{2}{|c}{$\begin{array}{c}\text { The Percentage Of Ket. } \\
\text { Communication (\%) }\end{array}$} \\
\cline { 2 - 3 } & $\begin{array}{c}\text { value of the } \\
\text { beginning }\end{array}$ & $\begin{array}{c}\text { value of the } \\
\text { ending }\end{array}$ \\
\hline \multicolumn{1}{|c|}{ Actively build dialog words } & 15.74 & 59.26 \\
\hline $\begin{array}{l}\text { Revealing } \\
\text { effectively }\end{array}$ & 15.74 & 82.41 \\
\hline $\begin{array}{l}\text { Convey ideas or } \\
\text { questions }\end{array}$ & 20.37 & 79.63 \\
\hline $\begin{array}{l}\text { Listen attentively and } \\
\text { politely good body }\end{array}$ & 62.96 & 77.78 \\
\hline $\begin{array}{l}\text { Shows } \\
\text { language }\end{array}$ & 29.26 & 77.22 \\
\hline Average aved
\end{tabular}

Based on average percentage value then increases collaboration skills of $47.96 \%$ of categories less well while the results of the analysis show that the increase in gain score categories are of 0.681 . The following graph from collaborative skills increase average score assessment of the beginning and end of 5.85 and 15.45 .

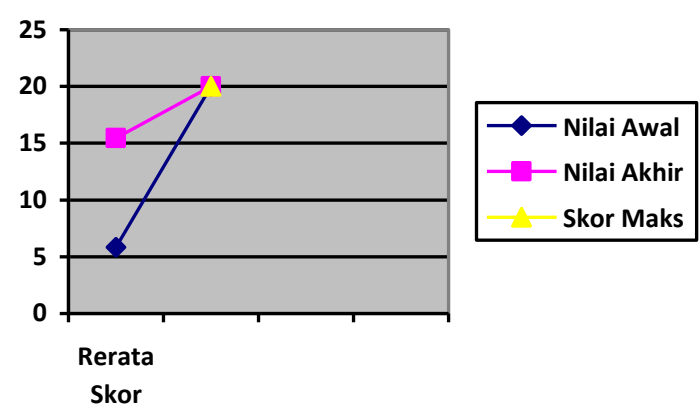

Figure 1. Diagram Of The Improved Communication Skills

The results of the analysis of the test Umann Whitney also shows LKPD IPA can improve collaboration skills learners significantly with Asymp. SIG (2-tailed) is 0.000 .

Based on the above explanation, then LKPD IPA-based model of project based learning can significantly improve communication skills learners. In accordance with the opinion of the Bell (2010: 41) stating that the execution of child sosal and sensitivity improve skills against the skills of the 21st century include communication skills by being a good listener and negotiate in taking decisions as well as appreciate friends sharing ideas in the team. Lindsay (Boss \& Krauss, 2007: 20) stating that through project-based learning, students get an extra advantage beyond the expected one of these learners can build communication skills.

\section{SUMMARY AND ADVICE}

Summary

1. LKPD IPA meets the eligibility based on components of A category value LKPD "very good" and have met the eligibility over aspects of the linguistic content, the eligibility of components, presentation, and kegrafisan with an A on every aspect and category "very good".

2. Collaboration skills enhancement learner using IPA are categorized LKPD of $31.54 \%$ of the 
category "enough" to "good". This was confirmed by the test results of the MannWhitney U gained Asymp. SIG (2-tailed) for 0.000 which means there is a significant difference between the skills of collaboration before, and after using LKPD.

3. Increasing communication skills learners using IPA are categorized LKPD of $47.96 \%$ of the category of "less" to "good". This was confirmed by the test results of the MannWhitney U Asymp is obtained. SIG (2-tailed) for 0.000 which means there is a significant difference between communication skills prior to, and after using LKPD.

4. Learner response against $A$ value obtained LKPD IPA with the category "very good".

\section{Advice}

Should the overall stages of project based learning is done per project, so the observation skills of collaboration and communication can be observed in nearly every project.

\section{BIBLIOGRAPHY}

Bell, S. (2010). Project-Based Learning for The 21st Century: Skills for The Future. The Cleaning House: A Journal of Educational, Strategic Issues and Ideas. Volume 83, 39-43.

Borich, G.D. (2003). Observation for Effective Teaching: Reaching-Based Practice. Seventh Edition. New York: M M Publishing Company.

Boss, S. \& Krauss, J. (2013). Thinking Through Project-Based Learning Guiding Deeper Inquiry. United States of America: SAGE Publications.

Eko Putro Widoyoko. (2014). Assessment of learning outcomes in school.. Yogyakarta: Student Library.

Hake, Richard R. (1998). Interactive-Engagement Versus Traditional Methods: A Six-
Thousand-Student Survey of Mechanics Test Data for Introductory Physics Courses. American Journal of Physics, vol. 66 No. 1, 64-74.

Eko Putro Widoyoko. (2009). The Evaluation Of The Learning Program. Yogyakarta: Student Library.

Igballe, Miftari, tetova, Macedonia 1200. (2014). Project Based Learning: Developing 21 st Century Collaborative and Technology Skills. European Journal of Research on Education. 52-57.

English Skills Report. (2010). Trends in Demand, Skills Gap, and Supply in Indonesia. Report No. 54741-EAP.

Melda Ariyanti. (2017). Comparison of the effectiveness of Project-Based Learning and Probem-Base Learning in terms of Ketercapaian learning objectives. Mathematics and Science Education Journal, V (1), 1-10.

Orey, M. (2010). Global Text: Emerging Perspectives on Learning, Teaching, and Technology. Switzerland: Catherine Land.

Thiagarajan, S., Semmel Semmel, D.S. \&, Myocardial Infarction And (1974). Instructional Development for Training Teachers of Exceptional Children. Bloomington: Indiana University.

Trilling, Bernie, Charles Fadel. (2009). 21st Century Skills: Learning for Live in Our Times. San Francisco: Jossey-Bass.

Yuni Wibowo, Suratsih, \& Asri Widowati. (2015). Increase in the ability of the Students in designing the curriculum through the implementation of Project Based Learning. Mathematics and Science Education Journal, 3 (1), 49-58.

Widodo Matthew Wibowo. (2014). Implementation of the Model ProjectBased Learning (the execution) in Learning to build 4cs Skills Learners as a Provision in the face of the challenges of the 21 st century. National seminar on IPA V Year 2014. 